KOLOM ILMIAH

Science And Technology

\title{
EKSISTENSI FOLKLORE SUMBAWA DI ERA DIGITAL (KEBERADAAN FOLKLORE DALAM MASYARAKAT SUMBAWA KHUSUSNYA ANAK-ANAK SEKOLAH DASAR TINGKAT PERTAMA DI KOTA SUMBAWA BESAR)
}

\author{
Vivin Nila Rakhmatullah, S.S., M.A., ${ }^{1}$ Wirentake, M.Pd. ${ }^{2}$ \\ ${ }^{12}$ Fakultas Teknik Universitas Teknologi Sumbawa \\ Email: vivin.nila.rakhmatullah@uts.ac.id, wirentake@uts.ac.id
}

\begin{abstract}
ABSTRAK
Diterima

Bulan Januari

2019

Diterbitkan

Bulan Januari

2019

Kata Kunci: budaya, folklore, permainan, digital

Samawa sebagai salah satu suku terbesar di provinsi Nusa Tenggara Barat, memiliki adat-istiadat yang kaya akan makna dan fungsi sosial budaya. Pesatnya perkembangan teknologi, saat ini budaya folklore mulai tersisihkan keberadaannya. Penelitian ini bertujuan untuk menelusuri keberadaan folklore dalam masyarakat Sumbawa terutama pada anak-anak sebagai generasi penerus. Sejauh mana anak-anak yang lahir dan tumbuh pada era digital mengetahui atau memahami beberapa tradisi adat-istiadat para leluhur terutama yang terkandung dalam folklore Sumbawa. Diharapkan dengan adanya penelitian mengenai keberadaan folklore di masyarakat Sumbawa khususnya anak-anak pada jaman digital ini, maka akan ada usaha, aksi atau kegiatan berkelanjutan untuk semakin menjaga, memelihara serta meningkatkan kesadaran masyarakat akan pentingnya menumbuhkan kembali nilai-nilai moral yang terdapat melalui folklore Sumbawa. Hasil yang diperoleh dari penelitian ini, para siswa Sekolah Dasar lebih mengenal permainan digital daripada permainan tradisional. Bagi siswa permainan tradisional kurang menarik dari permainan digital. Minat para siswa dalam memainkan permainan tradisional Sumbawa lebih rendah dari permainan digital. Informasi mengenai permainan tradisional lebih sedikit dibandingkan informasi mengenai permainan digital. Adapun metode penelitian yang digunakan dalam penelitian ini adalah metode deskriptif dan pengumpulan data dilakukan dengan teknik survei dan penyebaran questioner.
\end{abstract}

\section{PENDAHULUAN}

Samawa merupakan salah satu dari tiga suku besar di provinsi Nusa Tenggara Barat yang mendiami bagian barat pulau Sumbawa. Mereka menyebut diri mereka sebagai orang Sumbawa atau "Tau Samawa" dan menggunakan "Basa Samawa" sebagai bahasa sehari-hari. Suku Samawa sangat kaya akan budaya dan adat istiadat, termasuk budaya folklore.

Folklore, merupakan bagian dari budaya rakyat, terdiri dari dua kata "folk" dan "lore". Folk adalah istilah yang mengacu pada suatu kelompok masyarakat yang saling membagi tradisi dan karakteristik yang sama. Biasanya mengacu pada cara hidup tradisional suatu kelompok masyarakat (Watts, 2007). Menurut Allan Dundes, term "Folk" merupakan sekelompok orang yang memiliki kesamaan karakter fisik, sosial, dan budaya, yang bisa dibagi menjadi kelompok sosial dan budaya (Dananjaja, 1984). Masih menurut Danandjaja, istilah "lore" merupakan bagian dari budaya, yang diwariskan secara turun temurun dari satu generasi ke generasi berikutnya disampaikan secara lisan atau melalui sebuah contoh tanda, lambang atau berdasarkan daya ingat (Danandjaja, 1984).

Budaya folklore terbagi dalam tiga bagian berdasarkan keberadaannya, yakni Verbal (Lisan), Non-Verbal (Non-Lisan) dan Partly-Verbal (Sebagian Lisan) (Brunvand, 1968). Yang termasuk dalam budaya Lisan (Verbal) yaitu cerita rakyat dan lagu daerah, sedangkan Sebagian Lisan (Partly-Verbal) terdiri dari kesenian rakyat berupa seni pahat dan seni ukir, kemudian Non-Lisan (Non-Verbal) terdiri dari permainan, tebak-tebakan, dan takhayul/mitos. Dalam masyarakat Sumbawa, budaya folklore sendiri memiliki banyak jenis dengan makna dan nilai-nilai yang terkandung di dalamnya. Salah satunya bisa dilihat dari beberapa permainan tradisional yang merupakan budaya folklore Non-Lisan, seperti; takenjil, kendese, benteng, majang besio, serta masih banyak lagi.

Terdapat banyak sekali fungsi yang beraneka macam dari folklore. Beberapa fungsi umum yang diketahui yaitu; untuk menambah ilmu, untuk mendidik anak, untuk menanamkan nilai moral, untuk mengenang atau mengabadikan suatu kejadian/peristiwa bersejarah dalam suatu 


\section{JURNAL TAMBORA}

Vol. 3 No. 1 Februari 2019

kelompok masyarakat, untuk mempromosikan rasa solidaritas suatu kelompok/masyarakat, juga sebagai alat atau bentuk protes sosial, serta sebagai salah satu bentuk pelarian dari kenyataan, dan lainlain (Dundes, 1965). Salah satu fungsi yang penting dalam folklore Non-Lisan pada permainan tradisional rakyat adalah untuk mendidik dan menanamkan nilai moral pada anak-anak. Hal inilah yang perlu diketahui eksistensi atau keberadaan folklore saat ini dengan nilai moral yang terkandung.

\section{LANDASAN TEORI}

\section{Munculnya Permainan Digital}

Perkembangan teknologi pada beberapa tahun ini sangat pesat, terutama perkembagan teknologi telepon genggam dan sejenisnya. Telepon genggam mulai menjamur dengan berbagai macam bentuk, ukuran, keunikan masing-masing serta fungsi, tentu selain fungsi utama sebagai perangkat komunikasi. Tidak ketinggalan pula perkembangan aplikasi yang terdapat di dalam perangkat telepon genggam, atau perangkat teknologi lainnya. Semua berkembang dengan cepat seiring dengan banyaknya permintaan akan alat komunikasi seperti telpon genggam.

Berkembangnya fungsi telepon genggam, selain sebagai alat komunikasi, yaitu memenuhi "lifestyle" atau gaya hidup masyarakat jaman sekarang. Maka fungsi awal dari telepon genggam sebagai alat komunikasi mulai bergeser sedikit dengan tambahan beberapa fungsi lainnya untuk memenuhi kebutuhan, seperti kebutuhan akan hiburan. Hiburan melalui telepon genggam atau alat komunikasi lainnya (tab/iPad), mulai dipenuhi seperti penambahan pada aplikasi atau fitur-fitur untuk hiburan, yaitu permainan, musik, video, dan lain-lain.

Dengan pesatnya perkembangan teknologi terutama teknologi komunikasi dan teknologi informasi, budaya folklore semakin tersisihkan keberadaannya. Teknologi komunikasi dan teknnologi informs merambah ke semua kalangan, termasuk anak-anak dalam bentuk teknologi digital seperti gadget. Salah satu faktor penyebabnya adalah, mudah dan murahnya akses internet, banyaknya jenis alat komunikasi, alat permainan digital, dan berbagai contoh lain dari berkembangnya teknologi saat ini yang turut menggusur keberadaan folklore di masyarakat, terutama anak-anak. Mereka lebih banyak menggunakan permainan yang terdapat pada alat digital seperti telepon genggam atau tab/iPad daripada melakukan kegiatan bermain secara outdoor, di luar ruangan seperti lapangan, halaman atau tanah lapang. Sehingga semakin berkurang interaksi sosial dengan dunia luar dan juga lunturnya nilai-nilai moral yang harusnya dimiliki oleh tiap individu termasuk anak-anak. Berkurang pula pembelajaran sosial yang nyata di luar dengan orang lain.

Anak-anak sebagai generasi penerus, yang diharapkan dapat menjaga, mempertahankan, serta meneruskan kembali ke generasi berikutnya semua nilai yang ada dalam budaya rakyat/folklore seperti dalam permainan tradisional. Seharusnya sekarang ini saat anak-anak berada dalam masa bermain sambil belajar dapat menerima dan mempelajari berbagai macam permainan tradisional yang mengandung nilai moral yang mendidik. sehingga terjadi pula proses transmisi budaya dari generasi sebelumnya ke generasi berikutnya, yaitu anakanak.

Oleh karena itu, perlu dilakukan banyak kajian ataupun penelitian untuk menelusuri keberadaan folklore dalam masyarakat Sumbawa terutama pada anak-anak sebagai generasi penerus. Sejauh mana anak-anak yang lahir dan tumbuh pada era digital mengetahui atau memahami beberapa tradisi adatistiadat para leluhur terutama yang terkandung dalam folklore Sumbawa.

\section{METODOLOGI}

\section{Metode Deskriptif, Teknik Survey dan Penyebaran Questioner}

Metode penelitian yang digunakan dalam penelitian ini adalah metode deskriptif dan pengumpulan data dilakukan dengan teknik survey dan penyebaran questioner yaitu suatu metode dalam meneliti status kelompok manusia, suatu objek, suatu set kondisi, suatu sistem pemikiran ataupun suatu kelas peristiwa pada masa sekarang. Tujuannya adalah untuk membuat deskripsi, gambaran atau lukisan secara sistematis, faktual dan akurat mengenai fakta-fakta, sifat-sifat serta hubungan fenomena yang diselidiki (Nazir, 1985).

Proses pengumpulan data dalam penelitian ini menggunakan teknik pengumpulan data yang dilakukan dengan teknik survey, yaitu dengan mengumpulkan data dari sejumlah individu (unit sampling) dalam waktu yang bersamaan untuk menggambarkan keadaan populasi dengan menggunakan daftar pertanyaan (quistioner) terstruktur yang telah dipersiapkan sebelumnya.

Penelitian ini dilakukan di Kota Sumbawa Besar sebagai ibukota kabupaten Sumbawa dan salah satu kota terbesar di pulau Sumbawa. Dari 377 total Sekolah Dasar/Madrasah Ibtidaiyah di Kabupaten Sumbawa (www.sumbawa.siap.web.id), diambil perwakilan tiga sekolah dasar negeri dan 1 sekolah dasar swasta di kota Sumbawa Besar, yaitu SDIT Samawa Cendekia, SDN 2 Sumbawa Besar, SDN 1 Sumbawa Besar dan SDN 14 Sumbawa Besar. Dengan pertimbangan bahwa empat sekolah tersebut merupakan sekolah dasar terdepan dan berprestasi, mewakili sekolah negeri yang sudah lama berdiri dan juga sekolah swasta yang baru berdiri.

Dari empat SD/SDIT yang dipilih, penelitian dilakukan terhadap anak-anak sekolah dasar tingkat 


\section{JURNAL TAMBORA}

Vol. 3 No. 1 Februari 2019

pertama (kelas 1) dengan pertimbangan bahwa anak-anak tersebut merupakan anak-anak yang lahir dan tumbuh di jaman digital beberapa tahun terakhir ini. Maka akan ada sekitar empat kelas (kelas 1/tingkat pertama) dari masing-masing Sekolah Dasar yang akan menjadi sampel penelitian ini.

\section{HASIL DAN PEMBAHASAN}

\section{Permainan Rakyat Vs Permainan Digital}

Setelah melalui proses pengumpulan data, pengujian data dengan Sign Test (Uji Tanda) untuk mendapatkan hasil yang akurat. Maka data yang sudah diperoleh sebelumnya diolah untuk mengetahui hasil serta kesimpulan dari penelitian ini. Adapun pengolahan data dimulai dengan dipilihnya empat sekolah dasar di kota Sumbawa Besar secara acak untuk pengisian kuisioner (dapat dilihat pada lampiran 3). Diperoleh 96 siswa-siswi kelas 1 dari 4 Sekolah Dasar tersebut untuk pengisian kuisioner dan memberikan penilaian tentang keberadaan permainan rakyat di lingkungan siswa, ketertarikan siswa terhadap permainan rakyat, minat siswa dalam memainkan permainan tradisional Sumbawa dan permainan digital, kemudian yang terakhir adalah informasi mengenai permainan tradisional.

Penilaian terdiri dari 4-poin skala yaitu sebagai berikut:

$1=$ permainan (tradisional/digital) sangat tidak menarik,

$2=$ permainan $($ tradisional/digital) tidak menarik,

3 = permainan (tradisional/digital) menarik,

$4=$ permainan $($ tradisional $/$ digital) sangat menarik.

Dalam penelitian ini penulis membandingkan dua populasi dengan skala ordinal. Dari 96 siswa yang memberi penilaian kepada dua jenis permainan, maka data-data yang diperoleh adalah data yang berpasangan. Untuk mengetahui perbandingan keberadaan permainan rakyat di lingkungan siswa, ketertarikan siswa terhadap permainan rakyat, minat siswa dalam memainkan permainan tradisional Sumbawa dan permainan digital, serta informasi mengenai permainan tradisional maka digunakan uji tanda dengan uji hipotesis satu sisi, adapun hippotesis sebagai berikut:

$H_{0}=$ Permainan tradisional sama menariknya dengan permainan digital

$H_{a}=$ Permainan tradisional kurang menarik dari permainan digital

Dilakukan pengujian dengan taraf signifikan: $\alpha=$ 0,05

Dengan pembahasan sebagai berikut:

Pertama, dari pengujian data sebelumnya yaitu, siswa lebih mengenal permainan digital.
Dengan kata lain, siswa hanya mengetahui beberapa jenis permainan tradisional dibandingkan permainan digital. Pengetahuan siswa mengenai permainan tradisional masih sangat minim, yang disebabkan oleh beberapa faktor seperti kurangnya informasi mengenai permainan tradisional di lingkungan siswa tersebut, padatnya waktu belajar di dalam kelas, banyaknya kegiatan belajar di luar kelas, dan lain-lain.

Poin ke-dua yang didapat yaitu, siswa lebih tertarik dengan permainan digital daripada permainan tradisional. Selanjutnya, minat siswa dalam memainkan permainan tradisional Sumbawa lebih rendah dari permainan digital. Terdapat beberapa permainan tradisional yang kadang masih dimainkan oleh beberapa/sebagian kecil siswa SD, tapi untuk sebagian besar siswa tidak terlalu berminat untuk memainkan permainan tradisional tersebut.

Hasil terakhir yang didapatkan penulis yaitu, siswa Sekolah Dasar mendapatkan informasi mengenai permainan tradisional lebih sedikit dibandingkan informasi mengenai permainan digital. Informasi di masyarakat mengenai permainan tradisional memang tidak sebanyak informasi mengenai permainan digital, seiring dengan semakin menurunnya minat anak-anak dalam memainkan permainan tradisional. Beberapa siswa yang mendapatkan informasi mengenai permainan tradisional diperoleh dari keluarga dekat dan teman.

Dari pembahasan di atas, dapat dilihat bagaimana kurangnya minat serta ketertarikan siswa terhadap permainan rakyat atau permainan tradisional dan minimnya informasi mengenai permainan tradisional. Beberapa alasan siswa lebih tertarik kemudian lebih memilih permainan digital dibanding permainan tradisional, antara lain:

Permainan tradisional membutuhkan tempat yang luas untuk bermain, bagi pemainan tertentu. Sedangkan permainan digital tidak membutuhkan tempat atau ruang yang luas untuk bermain, beberapa permainan digital bisa dimainkan dimanapun.

Permainan tradisional membutuhkan beberapa teman/partner untuk bermain, bagi pemainan tertentu. Sedangkan kebanyakan permainan digital tidak perlu membutuhkan teman/partner dalam bermain, sehingga gampang dan dapat dimainkan sendiri. Terlebih lagi, tampilan permainan digital seperti warna, suara, bahkan karakter dalam permainan tersebut sangat menarik, sesuai dengan selera anak-anak.

Walaupun di sisi lain, untuk permainan digital yang paling dibutuhkan adalah pulsa (pembayaran) untuk dapat menikmati atau memainkan beberapa permainan tersebut, tapi bagi siswa hal itu bukan sesuatu penghalang siswa untuk bermain permainan digital. Hal ini dikarenakan pulsa yang dibutuhkan bukan tanggungan mereka melainkan 


\section{JURNAL TAMBORA}

Vol. 3 No. 1 Februari 2019

tanggungan orang tua. Dengan semua alasan dan pertimbangan tersebut, maka lebih jelas bahwa siswa lebih tertarik memainkan permainan digital daripada permainan tradisional yang sudah ada dari jaman dahulu.

\section{PENUTUP}

\section{Kesimpulan}

Berdasarkan hasil dari penelitian ini, penulis sampai kepada beberapa kesimpulan yaitu:

1. Para siswa Sekolah Dasar (informan) lebih mengenal permainan digital daripada permainan tradisional.

2. Bagi siswa Sekolah Dasar (informan) permainan tradisional kurang menarik dari permainan digital, dengan kata lain permainan digital lebih menarik perhatian siswa.

3. Minat para siswa Sekolah Dasar (informan) dalam memainkan permainan tradisional Sumbawa lebih rendah dari permainan digital.

4. Informasi mengenai permainan tradisional lebih sedikit dibandingkan informasi mengenai permainan digital.

Dari kesimpulan di atas, dapat dilihat bahwa keberadaan folklore saat ini dalam masyarakat Sumbawa terutama pada anak-anak tingkat pertama Sekolah Dasar mulai berkurang.

\section{REFERENSI}

Brunvand. Jan, Harold. The Study of American Folklore. New York: W.W Norton \& Company. Inc, 1968

Brunvand. Jan, Harold. American Folklore: An Encyclopedia, New York \& London:
Garland Publishing, Inc. 1996.

Botkin, B.A. A Treasury of American Folklore: Stories, Ballads, And Traditions of The People, New York: Crown Publishers, 1944. Print.

Bronner. J, Simon. The Meaning of Folklore: The Analytical Essays of Alan Dundes, Utah: Utah State University Press, 2007. Print.

Danandjaja, James. Folklore Indonesia Ilmu Gosip, Dongeng dan lain lain, Jakarta: Grafitipers, 1984. Print.

Dinas Diknas Kabupaten Sumbawa. Kumpulan Cerita Rakyat Sumbawa: Tutir Tau Samawa. Sumbawa: Tiara Perkasa Sumbawa, 2006. Print.

Dundes, Alan. The Study of Folklore, New Jersey: Prentice-Hall, Inc., 1965. Print.

Pranajaya, Adi. Peribahasa Bahasa Sumbawa. Jakarta: AP Foundation, 2012. Print.

Nazir, M. Metode Penelitian. Jakarta: Ghalia Indonesia, 1985.

Noorduyn, J. Sejarah Sumbawa, Yogyakarta: Riak, 2007. Printed.

Selim, Abdul Gani. Seni Budaya Daerah Sumbawa. Sumbawa Besar: Griya Kreatif Sumbawa Besar, 1998. Print

Watts. S, Linda. Encyclopedia of American Folklore, New York: Facts on File, Inc, 2007.

Zulkarnain, Aries. Tradisi dan Adat Istiadat Samawa. Yogyakarta: Penerbit Ombak, 2011. Print. 